\title{
SENSE OF COHERENCE AND STRESS-COPING STRATEGIES IN OFFICERS OF DIFFERENT POLICE FORCE DIVISIONS
}

\author{
Janina MACIEJCZYK, Przemysław LISZKA \\ Faculty of Psychology, University of Finance and Management in Warsaw, Warsaw, Poland
}

Source of support: Own sources

Author's address: J. Maciejczyk, University of Finance and Management in Warsaw, e-mail: Janka.123@interia.pl

Introduction: The aim of the study was to assess the relationship between the sense of coherence and stress-coping strategies preferred by the officers of different police force divisions.

Methods: Sense of coherence was examined using Antonovsky's life orientation questionnaire (SOC-29), while stress-coping capabilities were examined by the Coping Inventory for Stressful Situations (CISS) by N.S. Endler and J.D.A. Parker. A total of 94 male police officers serving in different force divisions, i.e. prevention police, traffic police and criminal police, were studied.

Results: Policemen with a higher sense of coherence tend to choose problem-focused stresscoping strategies more often. Differences in the sense of coherence and stress-coping strategies were demonstrated between the officers of different police forces.

Discussion: The obtained data confirm the results presented in the literature of the subject suggesting that individuals with a high sense of coherence prefer the problem-focused stress-coping strategy, while individuals with a low sense of coherence tend to choose emotion-focused and avoidance-focused strategies.

Conclusions: 1 . High sense of coherence is positively correlated to the problem-focused strategy of stress management and negatively related with the emotion-focused and avoidancefocused strategies of stress management.

2. Officers serving in different police forces tend to present different levels of the sense of coherence. Prevention police officers are characterized by the highest sense of coherence as compared to traffic police officers and criminal police officers.

3. Officers serving in different police forces tend to prefer different stress-coping strategies. Problem-focused stress-coping strategies are chosen most often by prevention police officers and traffic police officers.

Keywords: sense of coherence, stress-coping strategies, police forces

Tables: 7 • Figures: 0 • References: 23 • Full-text PDF: http://www.pjamp.com • Copyright @ 2013 Polish Aviation Medicine Society, ul. Krasińskiego 54/56, 01-755 Warsaw, license WIML •Indexation: Index Copernicus, Polish Ministry of Science and Higher Education 


\section{INTRODUCTION}

Theoretical foundation of the study is based on the concept of the sense of coherence as a part A. Antonovsky's salutogenesis theory as well as the concept of stress-coping strategies by N.S. Endler and J.D.A. Parker. Specifically, the key concept of Antonovsky's salutogenesis theory are the generalized resistance resources, including the individual or environmental characteristics responsible for more or less effective management of stress. The personal determinant of stress management capabilities is the sense of coherence defined as a global orientation to perceive life as comprehensible, manageable and meaningful (Antonovsky, 1995). The sense of comprehensibility defines the degree to which the individual perceives the stimuli originating from their inner or outer environment as comprehensible, structured, consistent and clear. Individuals with a high sense of coherence expects the stimuli they encounter in future will be predictable and rational regardless of being desirable or non-desirable. The sense of manageability defines the degree to which the individual perceives the available resources as sufficient to cope with the encountered demands. Individuals with a high sense of manageability believes that it is very likely that everything would turn out according to their will or that everything would be manageable. The sense of rationality defines the degree to which the individual perceives the life to have sense to it from emotional standpoint and to be worth their efforts, dedication and involvement. Individuals with a high sense of rationality perceives problems to be challenges of a motivational, acceptance-favouring nature. All these three ways of reflecting reality are referred to by the common name of the sense of coherence.

The theory of stress-coping strategies by Endler and Parker is a derivative of the transactional model of stress proposed by R. Lazarus and S. Folkman, according to whom coping is "constantly changing cognitive and behavioral efforts to manage specific external and/or internal demands that are appraised as taxing or exceeding the resources of the person" (Lazarus, Folkman, 1984, p.141). Different stress-coping strategies play two principal roles. The first function is the problem-focused function that serves to change situation for the better or to change one's own behaviour. The other function is the emotion-focused function that consists in controlling emotions so that they do not slip out of control and negatively affect relationships with others. Coping is therefore considered to be a basic adaptation mechanism that involves two prin- cipal cognitive assessment processes: the primary process including the characteristics of the stress situation and the secondary process focused on one's own management resources or ability to access other resources. Thus-defined stress-coping process involves cognitive and behavioural functions aimed at changing one's situation for the better. Preference of specific management processes may be transformed into stress-coping strategies or strategies. The latter are referred to in the theory of stress-coping strategies by Endler and Parker (1990) that defines the stress-coping strategy as a relatively constant personality disposition for particular manner of coping with stress situations. This disposition of the attribute of the subject and does not depend on the type of stress situation. Individual coping strategies determine individual differences in stress-coping within populations. This, however, does not imply that stresscoping strategies equally affect coping with each stress situations, as these are complex and multidimensional (Heszen-Niejodek, 1996). The authors of the theory identify three stress-coping strategies: problem-focused, emotion-focused and avoidance-focused.

The relationship between the sense of coherence and the stress-coping strategies is a consequence of the very essence of Antonowsky's salutogenesis theory (1979) that assumes that the human system is by its nature in heterostatic imbalance between its capabilities and environmental demands, with stress being a natural attribute of this imbalance. Regardless of whether the stressors are of internal, or external origin, we constantly encounter stimuli to which we have no ready and adequate adaptation responses at hand and yet to which we must somehow respond. One of the main mechanisms responsible for coping with everyday stress, or to use Antonovsky's terms, responsible for keeping the individual closer to the "health" pole than to the "disease" pole is the sense of coherence with its three components, i.e. the sense of comprehensibility, manageability and rationality. Literature data suggest that individuals with a high sense of coherence tend to manage stress better by treating it rather as a challenge than as a threat, which is of motivational value for becoming involved in pro-health activities and avoiding behaviours harmful to one's health in everyday life (Waszkowska, Dudek, 2001; Terelak, Gumkowska, 2002; Volanen et al., 2007) ,

The most important role of the sense of coherence is to modulate the course of the stress trans- 
action, allowing to manage one's resources in an optimum manner. Although the literature data provide no unambiguous answers regarding the direction of the correlation between the sense of coherence and the stress-coping strategies, much empirical data are available on the relationships between individual components of the sense of coherence and the preferred strategies (Jelonkiewicz, Kosińska-Dec, 2001). For example, studies conducted by Pasikowski (2000) showed that both the global sense of coherence (SOC) scores and their individual components are negatively related to the avoidance-focused and emotion-focused coping strategies. In the studies conducted by Terelak and Sniegoczyńska (2007) in the airborne personnel of PLL LOT airlines, natural preselection was detected as corresponding to different levels of the sense of coherence correlated to two strategies of coping, namely the problem-focused and the emotion-focused strategy. Similar results were obtained earlier by Mrozik, Czabała and Zwoliński (1993) in a group of unemployed individuals and by Piórkowski (2008) in professional military commanding officers.

These studies confirm the assumptions made by $A$. Antonovsky and referred to in this article suggesting that it is characteristic for individuals with a low sense of coherence to adapt less favorable stress-coping strategies, while individuals with high sense of coherence tend to take up optimum measures in stress situations.

Following hypotheses were formulated:

- H.1. There is a correlation between the sense of coherence and stress-coping strategies in police officers of different force divisions.

- H.2. There are individual differences in the sense of coherence between police officers of different force divisions.

- H.3. There are individual differences in stresscoping strategies between police officers of different force divisions.

\section{METHODS}

The study method included two questionnaires:

Life Orientation Questionnaire (SOC-29), by Aaron Antonovsky, adapted to Polish by Dudek and Makowska (1993). The questionnaire is used to measure three components of the sense of coherence as expressed in three scales: a) scale of the sense of comprehensibility that defines the degree to which the individual perceives the stimuli originating from their inner or outer environment as comprehensible, structured, consistent and clear.
Individuals with a high sense of coherence expects the stimuli they encounter in future will be predictable regardless of being desirable or nondesirable; $b$ ) the scale of the sense of manageability defines the degree to which the individual perceives the available resources as sufficient to cope with the demands posed by the incoming stimuli. The resources required to cope with the demands are the resources owned by individuals themselves or by individuals they trust and may count on; c) the scale of the sense of rationality defines individual's motivation to act based on the belief that life has sense to it from emotional standpoint and that at least part of the problems they may encounter in life are worth their effort, dedication and involvement. The sum of scores in all three scales determines the overall sense of coherence.

Coping Inventory for Stressful Situations (CISS) by N.S. Endler and J.D.A. Parker, adapted to Polish by P. Szczepaniak, J. Strelau and K. Wrześniewski (1996) consists of five scales: a) Problem-Focused Coping Scale (PFCS) that describes problem solving by means of cognitive transformation or attempts to change the situation; b) EmotionFocused Coping Scale (EFCS) that describes the individual's tendency to focus on themselves and their own emotions, proneness to wishful thinking and fantasizing to reduce emotional tension; c) Avoidance-Focused Coping Scale (AFCS) that measures actions aimed at evasion of thinking about the stress and stress situation itself. The latter scale involves two sub scales: d) Distraction Scale (DS) and Social diversion scale (SDS).

\section{The characteristics of subjects}

Study subject population consisted of police officers of three force divisions: prevention police, traffic police and criminal police.

The occupation of a police officer is one of the most stressful occupations. It is associated with accomplishing tasks in difficult or dangerous situations and requires considerable emotional involvement. Long-term readiness to act, excessive duties and difficulties to reconcile professional duties with family life due to the nature of service are the burdening to police officers. Also important is the shift-based working schedule, night duties, working on Saturdays and Sundays, and occasional interruption of vacation, making a policeperson's work a continuous service (Czerwiński, W. 1998). Significant psychological burden is placed on police officers by situations encountered in everyday work: taking part in interventions, use of weapons, chase after culprits, dispersing aggressive crowds. A policeperson on 
duty encounters aggression, violence and human tragedies. Their duty is to inform families of deaths of their close ones. Police officers face the demand of adapting to different situations and making decisions quick and effectively. The police duties are fulfilled together with other officers; the efficiency of work often depends on the quality of mutual relationships or collaboration. In addition, police officers are involved in situations directly or indirectly placing their lives and health at risk. They are exposed to stress after death of their colleagues as well as upon interventions associated with human suffering. The work of a police officer is full of shocking and unpleasant events, leading to a strong condition of stress. If difficult situations occur too often and last too long, they may even lead to the worsening of health, incidence of somatic diseases or neurosis, referred to in the literature as posttraumatic stress disorder (PTSD) (Kazimierczak, Strelau, Zawadzki, 2012). Changes in the behaviours, attitude to work or colleagues are also observed. As a result, long-term stress may lead to emotional exertion and limited involvement in work. In addition, individuals may feel fatigue, anger, aversion to contacts with other people described as the burnout syndrome (Maslach, 2003). Difficulties in starting and completing tasks, problems with going to work and elongation of times required for completion of particular tasks are observed. This paper will not include a more detailed psychological characteristics of police officers, as it is available in the literature (Ogińska-Bulik, 2003;. Dąbrowska, Iwan, Żaboklicka-Madziar, 2007). These data show, among others, that work in different force divisions, e.g. prevention police, traffic police or criminal police is associated with different intensity of stress, in both quantitative and qualitative degrees. For this reason, the analysis conducted as part of this study included male officers of three force divisions from the municipal police department in Koszalin and the regional police department in Białogard: criminal police $(\mathrm{n}=28$; age 37.5 years; seniority 14 years), prevention police ( $n=34$; age 29 years; seniority 6.6 years) and traffic police ( $n=32$; age 34.6 years; seniority 10.9 years). Secondary education was completed by 21 officers in the criminal force, 29 officers in the prevention force and 29 officers in the traffic force. Higher education was completed by 7 officers in the criminal force, 5 officers in the prevention force and 3 officers in the traffic force.

Method - the studies conducted in 94 police officers were group-based and took place in social areas within the department's premises. The tests were conducted between May and July 2010.
Participation was voluntary and non-paid. The answers were provided anonymously. No interruptions occurred during the tests. The sample was incidental, i.e. the person conducting the survey invited individuals they encountered on that particular day.

\section{RESULTS}

The results of studies verifying the hypothesis $\mathrm{H} 1$ regarding the existence of relationship between the sense of coherence and stress-coping strategies preferred by police officers of different force divisions associated with duties characterized by different work-related stress loads are presented in Tables 1, 2 and 3.

As shown by the data in Table 1, all stress-coping strategies are correlated to all components of the sense of coherence (the sense of comprehensibility, the sense of manageability and the sense of rationality) as well as with the overall sense of coherence. Considering the above, the following detailed conclusions are justifiable:

a) the problem-focused stress-coping strategy in the prevention forces is positively correlated to the overall high sense of coherence as well as with high sense of comprehensibility, the sense of manageability and the sense of rationality in this group,

b) emotion-focused stress-coping strategy is: highly negatively correlated to overall sense of coherence and its individual components,

b) avoidance-focused stress-coping strategy is: highly negatively correlated to overall sense of coherence and its individual components.

Correlation results obtained in the traffic police forces are consistent with these obtained in the prevention police forces.

As shown in Table 3, statistically significant results in the preferred stress-coping strategies were observed for the problem-focused strategy in the criminal police force division as regards the problem-focused strategy $(p<0.001)$ and the emotionfocused strategy $(p<0.001)$. With respect to the difference in stress-coping strategies between the traffic and the criminal police forces, the emotionfocused strategy is the only strategy with a difference of statistical significance $(p<0.05)$.

As demonstrated by the analysis of data presented in the above tables, problem-focused stress-coping strategy is correlated to the sense of coherence also in the traffic and criminal police forces. Similarly as in the case of prevention forces, problem-focused strategy is positively correlated to all components of the sense of coherence as 
J. Maciejczyk, P. Liszka - Sense of coherence and stress-coping...

Tab. 1. Kendall coefficients of correlation between the sense of coherence and the stress-coping strategies in the officers of prevention police force division $(n=34)$.

\begin{tabular}{|c|c|c|c|c|c|c|c|c|c|}
\hline \multicolumn{10}{|c|}{ Correlations } \\
\hline & & & $\begin{array}{l}\text { Sense of } \\
\text { comprehen- } \\
\text { sibility }\end{array}$ & $\begin{array}{c}\text { Sense of } \\
\text { manage- } \\
\text { ability }\end{array}$ & $\begin{array}{c}\text { Sense } \\
\text { of rationality }\end{array}$ & $\begin{array}{l}\text { Overall } \\
\text { soc score }\end{array}$ & $\begin{array}{l}\text { Problem- } \\
\text { focused } \\
\text { strategy }\end{array}$ & $\begin{array}{l}\text { Emotion- } \\
\text { focused } \\
\text { strategy }\end{array}$ & $\begin{array}{c}\text { Avoidance- } \\
\text { focused } \\
\text { strategy }\end{array}$ \\
\hline & & & Prevention & Prevention & Prevention & Prevention & Prevention & Prevention & Prevention \\
\hline \multirow{21}{*}{$\begin{array}{l}\text { Ken- } \\
\text { dall } \\
\text { Tau-b }\end{array}$} & $\begin{array}{l}\text { Sense of compre- } \\
\text { hensibility }\end{array}$ & $\begin{array}{l}\text { Correlation } \\
\text { coefficient }\end{array}$ & 1.000 & $.788^{* *}$ & $.673^{* *}$ & $.904^{* *}$ & $.703^{* *}$ & $-.626^{* *}$ & $-.608^{* *}$ \\
\hline & Prevention & $\begin{array}{l}\text { Significance } \\
\text { (double-si- } \\
\text { ded) }\end{array}$ & . & .000 & .000 & .000 & .000 & .000 & .000 \\
\hline & & $\mathbf{n}$ & 34 & 34 & 34 & 34 & 34 & 34 & 34 \\
\hline & $\begin{array}{l}\text { Sense of manage- } \\
\text { ability }\end{array}$ & $\begin{array}{l}\text { Correlation } \\
\text { coefficient }\end{array}$ & $.788^{* *}$ & 1.000 & $.685^{* *}$ & $.892^{* *}$ & $.810^{* *}$ & $-.681^{* *}$ & $-.644^{* *}$ \\
\hline & Prevention & $\begin{array}{c}\text { Significance } \\
\text { (double-si- } \\
\text { ded) }\end{array}$ & .000 & . & .000 & .000 & .000 & .000 & .000 \\
\hline & & $\mathbf{n}$ & 34 & 34 & 34 & 34 & 34 & 34 & 34 \\
\hline & $\begin{array}{l}\text { Sense of ratio- } \\
\text { nality }\end{array}$ & $\begin{array}{l}\text { Correlation } \\
\text { coefficient }\end{array}$ & $.673^{* *}$ & $.685^{* *}$ & 1.000 & $.727^{* *}$ & $.651^{* *}$ & $-.566^{* *}$ & $-.680^{* *}$ \\
\hline & Prevention & $\begin{array}{c}\text { Significance } \\
\text { (double-si- } \\
\text { ded) }\end{array}$ & .000 & .000 & . & .000 & .000 & .000 & .000 \\
\hline & & $\mathbf{n}$ & 34 & 34 & 34 & 34 & 34 & 34 & 34 \\
\hline & Overall SOC score & $\begin{array}{l}\text { Correlation } \\
\text { coefficient }\end{array}$ & $.904^{* *}$ & $.892^{* *}$ & $.721^{* *}$ & 1.000 & $.781^{* *}$ & $-.662^{* *}$ & $-.625^{* *}$ \\
\hline & Prevention & $\begin{array}{c}\text { Significance } \\
\text { (double-si- } \\
\text { ded) }\end{array}$ & .000 & .000 & .000 & . & .000 & .000 & .000 \\
\hline & & $\mathbf{n}$ & 34 & 34 & 34 & 34 & 34 & 34 & 34 \\
\hline & $\begin{array}{l}\text { Problem-focused } \\
\text { strategy }\end{array}$ & $\begin{array}{l}\text { Correlation } \\
\text { coefficient }\end{array}$ & $.703^{* *}$ & $.810^{* *}$ & $.651^{* *}$ & $.781^{* *}$ & 1.000 & $-.735^{* *}$ & $-.649 * *$ \\
\hline & Prevention & $\begin{array}{c}\text { Significance } \\
\text { (double-si- } \\
\text { ded) }\end{array}$ & .000 & .000 & .000 & .000 & . & .000 & .000 \\
\hline & & $\mathbf{n}$ & 34 & 34 & 34 & 34 & 34 & 34 & 34 \\
\hline & $\begin{array}{l}\text { Emotion-focused } \\
\text { strategy }\end{array}$ & $\begin{array}{l}\text { Correlation } \\
\text { coefficient }\end{array}$ & $-.626^{* *}$ & $-.681^{* *}$ & $-.566^{* *}$ & $-.662^{* *}$ & $-.735^{* *}$ & 1.000 & $.554^{* *}$ \\
\hline & Prevention & $\begin{array}{c}\text { Significance } \\
\text { (double-si- } \\
\text { ded) }\end{array}$ & .000 & .000 & .000 & .000 & .000 & . & .000 \\
\hline & & $\mathbf{n}$ & 34 & 34 & 34 & 34 & 34 & 34 & 34 \\
\hline & $\begin{array}{c}\text { Avoidance-focused } \\
\text { strategy }\end{array}$ & $\begin{array}{l}\text { Correlation } \\
\text { coefficient }\end{array}$ & $-.608^{* *}$ & $-.644^{* *}$ & $-.680^{* *}$ & $-.625^{* *}$ & $-.649 * *$ & $.554^{* *}$ & 1.000 \\
\hline & Prevention & $\begin{array}{c}\text { Significance } \\
\text { (double-si- } \\
\text { ded) }\end{array}$ & .000 & .000 & .000 & .000 & .000 & .000 & . \\
\hline & & $n$ & 34 & 34 & 34 & 34 & 34 & 34 & 34 \\
\hline
\end{tabular}

** Correlation significant at 0.01 (double-sided)

well as with the overall sense of coherence. Thus, it may be assumed that the increase of one factor in these groups is associated with the increase in the other one as well. Emotion-focused stress-coping strategy is correlated to the sense of coherence in the traffic and criminal police forces. Similarly as in the case of prevention forces, emotion-focused strategy was negatively correlated to all components of the sense of coherence as well as with the overall sense of coherence. Thus, it may be assumed that the increase of one factor in these groups is associated with a reduction in the other one. Avoidance-focused stress-coping strategy is correlated to the sense of coherence in the pre- 
Original Article

Tab. 2. Kendall coefficients of correlation between the sense of coherence and the stress-coping strategies in the officers of traffic police force division $(n=32)$.

\begin{tabular}{|c|c|c|c|c|c|c|c|c|c|}
\hline \multicolumn{10}{|c|}{ Correlations } \\
\hline & & & $\begin{array}{c}\text { Sense of } \\
\text { comprehen- } \\
\text { sibility } \\
\text { Traffic }\end{array}$ & $\begin{array}{c}\text { Sense of } \\
\text { manage- } \\
\text { ability } \\
\text { Traffic }\end{array}$ & $\begin{array}{c}\text { Sense of } \\
\text { rationality } \\
\text { Traffic }\end{array}$ & $\begin{array}{c}\text { Overall SOC } \\
\text { score } \\
\text { Traffic }\end{array}$ & $\begin{array}{c}\text { Problem- } \\
\text { focused } \\
\text { strategy } \\
\text { Traffic }\end{array}$ & $\begin{array}{c}\text { Emotion- } \\
\text { focused } \\
\text { strategy } \\
\text { Traffic }\end{array}$ & $\begin{array}{c}\text { Avoidance- } \\
\text { focused } \\
\text { strategy } \\
\text { Traffic }\end{array}$ \\
\hline \multirow{21}{*}{$\begin{array}{l}\text { Ken- } \\
\text { dall } \\
\text { Tau-b }\end{array}$} & $\begin{array}{l}\text { Sense of compre- } \\
\text { hensibility }\end{array}$ & $\begin{array}{l}\text { Correlation } \\
\text { coefficient }\end{array}$ & 1.000 & $.581^{* *}$ & $.707^{* *}$ & $.788^{\prime}$ & $.727^{* *}$ & $-.688^{* *}$ & $-.409^{* *}$ \\
\hline & Traffic & $\begin{array}{c}\text { Significance } \\
\text { (double-si- } \\
\text { ded) }\end{array}$ & . & .000 & .000 & .000 & .000 & .000 & .002 \\
\hline & & $n$ & 32 & 32 & 32 & 32 & 32 & 32 & 32 \\
\hline & $\begin{array}{l}\text { Sense of manage- } \\
\text { ability }\end{array}$ & $\begin{array}{l}\text { Correlation } \\
\text { coefficient }\end{array}$ & $.581^{* *}$ & 1.000 & $.778^{* *}$ & $.803^{* *}$ & $.709^{* *}$ & $-.640^{* *}$ & $-.374^{* *}$ \\
\hline & Traffic & $\begin{array}{c}\text { Significance } \\
\text { (double-si- } \\
\text { ded) }\end{array}$ & .000 & . & .000 & .000 & .000 & .000 & .004 \\
\hline & & $\mathbf{n}$ & 32 & 32 & 32 & 32 & 32 & 32 & 32 \\
\hline & $\begin{array}{l}\text { Sense of ratio- } \\
\text { nality }\end{array}$ & $\begin{array}{l}\text { Correlation } \\
\text { coefficient }\end{array}$ & $.707^{* *}$ & $.778^{* *}$ & 1.000 & $.869^{* *}$ & $.715^{* *}$ & $-.740^{* *}$ & $-.368^{* *}$ \\
\hline & Traffic & $\begin{array}{c}\text { Significance } \\
\text { (double-si- } \\
\text { ded) }\end{array}$ & .000 & .000 & . & .000 & .000 & .000 & .005 \\
\hline & & $\mathbf{n}$ & 32 & 32 & 32 & 32 & 32 & 32 & 32 \\
\hline & Overall SOC score & $\begin{array}{l}\text { Correlation } \\
\text { coefficient }\end{array}$ & $.788^{* *}$ & $.803^{* *}$ & $.869 * *$ & 1.000 & $.783^{* *}$ & $-.700^{* *}$ & $-.407^{* *}$ \\
\hline & Traffic & $\begin{array}{c}\text { Significance } \\
\text { (double-si- } \\
\text { ded) }\end{array}$ & .000 & .000 & .000 & . & .000 & .000 & .001 \\
\hline & & $\mathbf{n}$ & 32 & 32 & 32 & 32 & 32 & 32 & 32 \\
\hline & $\begin{array}{l}\text { Problem-focused } \\
\text { strategy }\end{array}$ & $\begin{array}{c}\text { Correlation } \\
\text { coefficient }\end{array}$ & $.727^{* *}$ & $.709^{* *}$ & $.715^{* *}$ & $.783^{* *}$ & 1.000 & $-.661^{* *}$ & $-.484^{* *}$ \\
\hline & Traffic & $\begin{array}{c}\text { Significance } \\
\text { (double-si- } \\
\text { ded) }\end{array}$ & .000 & .000 & .000 & .000 & . & .000 & .000 \\
\hline & & $\mathbf{n}$ & 32 & 32 & 32 & 32 & 32 & 32 & 32 \\
\hline & $\begin{array}{l}\text { Emotion-focused } \\
\text { strategy }\end{array}$ & $\begin{array}{l}\text { Correlation } \\
\text { coefficient }\end{array}$ & $-.688^{* *}$ & $-.640 * *$ & $-.740 * *$ & $-.700^{* *}$ & $-.661^{* *}$ & 1.000 & .369 \\
\hline & Traffic & $\begin{array}{c}\text { Significance } \\
\text { (double-si- } \\
\text { ded) }\end{array}$ & .000 & .000 & .000 & .000 & .000 & . & .004 \\
\hline & & $n$ & 32 & 32 & 32 & 32 & 32 & 32 & 32 \\
\hline & $\begin{array}{c}\text { Avoidance-focused } \\
\text { strategy }\end{array}$ & $\begin{array}{l}\text { Correlation } \\
\text { coefficient }\end{array}$ & $-.409 * *$ & $-374^{* *}$ & $-.368^{* *}$ & $-.407^{* *}$ & $-.484^{* *}$ & $.369^{* *}$ & 1.000 \\
\hline & Traffic & $\begin{array}{c}\text { Significance } \\
\text { (double-si- } \\
\text { ded) }\end{array}$ & .002 & .004 & .005 & .001 & .000 & .004 & . \\
\hline & & $n$ & 32 & 32 & 32 & 32 & 32 & 32 & 32 \\
\hline
\end{tabular}

** Correlation significant at 0.01 (double-sided)

vention and traffic police forces. It is negatively correlated to all components of the sense of coherence as well as with the overall sense of coherence. Thus, it should be assumed that the increase of one factor in these groups is associated with a reduction in the other one. In the criminal force division, the avoidance-focused stress-coping strategy is only moderately negatively correlated with the sense of rationality and poorly negatively correlated with the overall sense of coherence, indicating that there is no relationship between the avoidance-focused strategy and the sense of coherence in that study group. 
J. Maciejczyk, P. Liszka - Sense of coherence and stress-coping...

Tab. 3. Kendall coefficients of correlation between the sense of coherence and the stress-coping strategies in the officers of criminal police force division $(n=28)$.

\begin{tabular}{|c|c|c|c|c|c|c|c|c|c|}
\hline \multicolumn{10}{|c|}{ Correlations } \\
\hline & & & $\begin{array}{l}\text { Sense of } \\
\text { comprehen- } \\
\text { sibility } \\
\text { Criminal }\end{array}$ & $\begin{array}{c}\text { Sense of } \\
\text { manage- } \\
\text { ability } \\
\text { Criminal }\end{array}$ & $\begin{array}{c}\text { Sense of } \\
\text { rationality } \\
\text { Criminal }\end{array}$ & $\begin{array}{c}\text { Overall SOC } \\
\text { score } \\
\text { Criminal }\end{array}$ & $\begin{array}{l}\text { Problem- } \\
\text { focused } \\
\text { strategy } \\
\text { Criminal }\end{array}$ & $\begin{array}{l}\text { Emotion- } \\
\text { focused } \\
\text { strategy } \\
\text { Criminal }\end{array}$ & $\begin{array}{c}\text { Avoidance- } \\
\text { focused } \\
\text { strategy } \\
\text { Criminal }\end{array}$ \\
\hline $\begin{array}{l}\text { Ken- } \\
\text { dall }\end{array}$ & $\begin{array}{l}\text { Sense of compre- } \\
\text { hensibility }\end{array}$ & $\begin{array}{l}\text { Correlation } \\
\text { coefficient }\end{array}$ & 1.000 & $.602^{* *}$ & $.444^{* *}$ & $.796^{*}$ & $.624^{* *}$ & $-.440^{* *}$ & $-.259^{* *}$ \\
\hline \multirow{2}{*}{\multicolumn{2}{|c|}{ Criminal }} & $\begin{array}{c}\text { Significance } \\
\text { (double-si- } \\
\text { ded) }\end{array}$ & . & .000 & .002 & .000 & .000 & .001 & .059 \\
\hline & & $\mathbf{n}$ & 28 & 28 & 28 & 28 & 28 & 28 & 28 \\
\hline & $\begin{array}{l}\text { Sense of manage- } \\
\text { ability }\end{array}$ & $\begin{array}{l}\text { Correlation } \\
\text { coefficient }\end{array}$ & $.602^{* *}$ & 1.000 & $.503^{* *}$ & $.794^{* *}$ & $.655^{* *}$ & $-.375^{* *}$ & $-.148^{* *}$ \\
\hline \multirow{2}{*}{\multicolumn{2}{|c|}{ Criminal }} & $\begin{array}{c}\text { Significance } \\
\text { (double-si- } \\
\text { ded) }\end{array}$ & .000 & . & .000 & .000 & .000 & .007 & .283 \\
\hline & & $\mathbf{n}$ & 28 & 28 & 28 & 28 & 28 & 28 & 28 \\
\hline & $\begin{array}{l}\text { Sense of ratio- } \\
\text { nality }\end{array}$ & $\begin{array}{l}\text { Correlation } \\
\text { coefficient }\end{array}$ & $.444^{* *}$ & $.503^{* *}$ & 1.000 & $.632^{* *}$ & $.716^{* *}$ & $-.473^{* *}$ & $-.347^{*}$ \\
\hline \multirow{2}{*}{\multicolumn{2}{|c|}{ Criminal }} & $\begin{array}{c}\text { Significance } \\
\text { (double-si- } \\
\text { ded) }\end{array}$ & .002 & .000 & . & .000 & .000 & .001 & .013 \\
\hline & & $\mathbf{n}$ & 28 & 28 & 28 & 28 & 28 & 28 & 28 \\
\hline & Overall SOC score & $\begin{array}{l}\text { Correlation } \\
\text { coefficient }\end{array}$ & $.796^{* *}$ & $.794^{* *}$ & $.632^{* *}$ & 1.000 & $.800^{* *}$ & $-.497^{* *}$ & $-.266^{*}$ \\
\hline \multirow{2}{*}{\multicolumn{2}{|c|}{ Criminal }} & $\begin{array}{c}\text { Significance } \\
\text { (double-si- } \\
\text { ded) }\end{array}$ & .000 & .000 & .000 & . & .000 & .000 & .050 \\
\hline & & $\mathbf{n}$ & 28 & 28 & 28 & 28 & 28 & 28 & 28 \\
\hline & $\begin{array}{l}\text { Problem-focused } \\
\text { strategy }\end{array}$ & $\begin{array}{l}\text { Correlation } \\
\text { coefficient }\end{array}$ & $.624^{* *}$ & $.655^{* *}$ & $.716^{* *}$ & $.800^{* *}$ & 1.000 & $-.565^{* *}$ & $-.402^{* *}$ \\
\hline \multirow{2}{*}{\multicolumn{2}{|c|}{ Criminal }} & $\begin{array}{c}\text { Significance } \\
\text { (double-si- } \\
\text { ded) }\end{array}$ & .000 & .000 & .000 & .000 & . & .000 & .004 \\
\hline & & $\mathbf{n}$ & 28 & 28 & 28 & 28 & 28 & 28 & 28 \\
\hline & $\begin{array}{c}\text { Emotion-focused } \\
\text { strategy }\end{array}$ & $\begin{array}{l}\text { Correlation } \\
\text { coefficient }\end{array}$ & $-.440^{* *}$ & $-.375^{* *}$ & $-.473^{* *}$ & $-.497^{* *}$ & $-.565^{* *}$ & 1.000 & .708 \\
\hline \multirow{2}{*}{\multicolumn{2}{|c|}{ Criminal }} & $\begin{array}{c}\text { Significance } \\
\text { (double-si- } \\
\text { ded) }\end{array}$ & .001 & .007 & .001 & .000 & .000 & . & .000 \\
\hline & & $\mathbf{n}$ & 28 & 28 & 28 & 28 & 28 & 28 & 28 \\
\hline & $\begin{array}{c}\text { Avoidance-focused } \\
\text { strategy }\end{array}$ & $\begin{array}{l}\text { Correlation } \\
\text { coefficient }\end{array}$ & $-.259^{* *}$ & $-.148^{* *}$ & $-.347^{*}$ & $-.266^{*}$ & $-.402^{* *}$ & $.708^{* *}$ & 1.000 \\
\hline \multirow{2}{*}{\multicolumn{2}{|c|}{ Criminal }} & $\begin{array}{c}\text { Significance } \\
\text { (double-si- } \\
\text { ded) }\end{array}$ & .059 & .283 & .013 & .050 & .004 & .000 & . \\
\hline & & $n$ & 28 & 28 & 28 & 28 & 28 & 28 & 28 \\
\hline
\end{tabular}

** Correlation significant at 0.01 (double-sided)

* Correlation significant at 0.05 (double-sided)

Verification of hypothesis $\mathrm{H} 2$, assuming intergroup differences in the sense of coherence between the officers of different police force divisions was verified using unifactorial ANOVA analysis and Tukey's test. The results are presented in Table 4.
As shown in Table 4, unifactorial ANOVA revealed that the differences between average results in the prevention police force and the average results in the traffic and criminal police forces are statistically significant at the level of $p=0.05$. No statistically significant difference was observed between the average results in the traffic 
Original Article

Tab. 4. Unifactorial ANOVA of inter-group differences in the sense of coherence between officers of different police force divisions.

\begin{tabular}{lccccc}
\hline & \multicolumn{2}{c}{$\begin{array}{l}\text { Unifactorial ANOVA } \\
\text { Sense of coherence }\end{array}$} \\
\hline Sum of squares & df & Mean square & F & 14.432 & Significance \\
\hline Within groups & 9626.642 & 2 & 4813.321 & & \\
\hline Overall & 30350.475 & 91 & 333.522 & & \\
\hline
\end{tabular}

Tab. 5. Tukey's HSD test results for the differences in the sense of coherence between police officers of different force divisions.

\begin{tabular}{|c|c|c|c|c|c|c|}
\hline \multicolumn{7}{|c|}{ Multiple comparisons } \\
\hline \multicolumn{7}{|c|}{ Dependent variable: sense of coherence } \\
\hline \multicolumn{7}{|c|}{ Tukey's HSD test } \\
\hline \multirow{2}{*}{ (I) Divisions } & \multirow{2}{*}{ (J) Divisions } & \multirow{2}{*}{ Difference in means } & \multirow{2}{*}{ Standard error } & \multirow{2}{*}{ Significance } & \multicolumn{2}{|c|}{$\mathbf{9 5} \%$ confidence interval } \\
\hline & & & & & Lower limit & Upper limit \\
\hline \multirow{2}{*}{ Prevention } & Traffic & $16.01471^{*}$ & 4.49800 & 0.002 & 5.2975 & 26.7319 \\
\hline & Criminal & $24.33613^{*}$ & 4.66057 & 0.000 & 13.2316 & 35.4407 \\
\hline \multirow{2}{*}{ Traffic } & Prevention & $-16.01471^{*}$ & 4.49800 & 0.002 & -26.7319 & -5.2975 \\
\hline & Criminal & 8.32143 & 4.72589 & 0.189 & -2.9388 & 19.5816 \\
\hline \multirow{2}{*}{ Criminal } & Prevention & $-24.33613^{*}$ & 4.66057 & 0.000 & -35.4407 & -13.2316 \\
\hline & Traffic & -8.32143 & 4.72589 & 0.189 & -19.5816 & 2.9388 \\
\hline
\end{tabular}

${ }^{*}$ Difference in means significant at 0.05

and criminal police forces. Therefore, one should assume that the tested prevention police officers were characterized by a higher level of the sense of coherence as compared to the officers of the remaining divisions included in the study.

To make this analysis deeper, it was interesting to confirm the individual components of the sense of coherence between the groups using Tukey's HSD test. The results of multiple comparisons are presented in Table 5.

Analysis of results in Table 5 allows to assume that the tested officers differ significantly in terms of the average results of individual components of the sense of coherence. The average level of the sense of comprehensibility in the prevention forces was higher than in the traffic and criminal police forces. The differences in the average results of the sense of comprehensibility are higher at the statistical level of $p=0.001$, compared to both the traffic and the criminal police forces. The second component of the overall sense of coherence - the sense of manageability - also differentiates the prevention division from the remaining division. The differences in the means are statistically significant at the level of $p=0.01$ with respect to the traffic division and $p=0.001$ with respect to the criminal division. When it comes to the third component of the sense of coherence, i.e. the sense of rationality, the average score in the prevention division was higher from the average results obtained in the officers from the traffic and criminal divisions.
The differences in the means are statistically significant at the level of $p=0.01$ with respect to the traffic division and $p=0.001$ with respect to the criminal division, as well as at the level of $p=0.01$ for the comparison between the traffic and criminal divisions.

Verification of hypothesis $\mathrm{H} 3$ assuming intergroup differences in stress-coping strategies between police officers of different force divisions. It was assumed that the problem-focused stresscoping strategy was predominant in the officers of prevention police and traffic police, while the criminal police officers demonstrated a preference for choosing the emotion-focused strategy. The results of the analysis are presented in Tables 6 and 7.

The results of unifactorial ANOVA as regards the differences in the preferences of stress-coping strategies are statistically significant for the problem- and emotion-focused strategies and non-significant in case of the avoidance-focused strategy. This is confirmed by another analysis that takes in to account the differences in the preferences of stress-coping strategies between police officers from different force divisions while making use of the Tukey's HSD test. The results of multiple comparisons are presented in Table7.

Analysis of results presented in Table 7 reveals variability of stress-coping strategies between police officers serving in different force divisions characterized by different professional stress bur- 
J. Maciejczyk, P. Liszka - Sense of coherence and stress-coping...

Tab. 6. Unifactorial ANOVA for the inter-group differences in stress-coping strategies between police officers of different force divisions.

\begin{tabular}{|c|c|c|c|c|c|c|}
\hline & & Sum of squares & df & Mean square & $\mathbf{F}$ & $\begin{array}{l}\text { Significance of } \\
\text { difference }\end{array}$ \\
\hline \multirow{3}{*}{$\begin{array}{l}\text { Problem-focused } \\
\text { strategy }\end{array}$} & Between groups & 2342.000 & 2 & 1171.00 & 10.027 & .000 \\
\hline & Within groups & 9459.750 & 81 & 116.787 & & \\
\hline & Overall & 11801.750 & 83 & & & \\
\hline \multirow{3}{*}{$\begin{array}{l}\text { Emotion-focused } \\
\text { strategy }\end{array}$} & Between groups & 6721.167 & 2 & 3360.583 & 10.882 & .000 \\
\hline & Within groups & 25013.643 & 81 & 311.793 & & \\
\hline & Overall & 31734.610 & 83 & & & \\
\hline \multirow{3}{*}{$\begin{array}{l}\text { Avoidance-focused } \\
\text { strategy }\end{array}$} & Between groups & 374.738 & 2 & 187.369 & 1.886 & .158 \\
\hline & Within groups & 8046.500 & 81 & 99.340 & & \\
\hline & Overall & 8421.238 & 83 & & & \\
\hline
\end{tabular}

Tab. 7. Tukey's HSD test results for the differences in the stress-coping strategies in police officers of different force divisions.

\begin{tabular}{|c|c|c|c|c|c|c|c|}
\hline \multicolumn{8}{|c|}{$\begin{array}{c}\text { Multiple comparisons } \\
\text { Tukey's HSD test }\end{array}$} \\
\hline \multirow[t]{2}{*}{ Dependent variable } & \multirow[t]{2}{*}{ (1) Divisions } & \multirow[t]{2}{*}{ (J) Divisions } & \multirow{2}{*}{$\begin{array}{l}\text { Difference in } \\
\text { means (I-J) }\end{array}$} & \multirow[t]{2}{*}{ Standard error } & \multirow[t]{2}{*}{ Significance } & \multicolumn{2}{|c|}{$\mathbf{9 5} \%$ confidence interval } \\
\hline & & & & & & Lower limit & Upper limit \\
\hline \multirow{6}{*}{$\begin{array}{l}\text { Problem-focused } \\
\text { strategy }\end{array}$} & \multirow{2}{*}{ Prevention } & Traffic & $8.21875^{*}$ & 2.63990 & .007 & 1.9288 & 14.5087 \\
\hline & & Criminal & $12.03571^{*}$ & 2.73531 & .000 & 5.5184 & 18.5530 \\
\hline & \multirow{2}{*}{ Traffic } & Prevention & $-8.21875^{*}$ & 2.63990 & .007 & -14.5087 & -1.9288 \\
\hline & & Criminal & 3.81696 & 2.77365 & .358 & -2.7917 & 10.4256 \\
\hline & \multirow{2}{*}{ Criminal } & Prevention & $-12.03571^{*}$ & 2.73531 & .000 & -18.5530 & -5.5184 \\
\hline & & Traffic & -3.81696 & 2.77365 & .358 & -10.4256 & 2.7917 \\
\hline \multirow{6}{*}{$\begin{array}{l}\text { Emotion-focused } \\
\text { strategy }\end{array}$} & \multirow{2}{*}{ Prevention } & Traffic & $-11.08640^{*}$ & 4.34901 & .033 & -21.4486 & -.7242 \\
\hline & & Criminal & $-22.01050^{*}$ & 4.50620 & .000 & -32.7473 & -11.2737 \\
\hline & \multirow{2}{*}{ Traffic } & Prevention & $11.08640^{*}$ & 4.34901 & .033 & .7242 & 21.4486 \\
\hline & & Criminal & $-10.92411^{*}$ & 4.56936 & .049 & -21.8113 & -.0369 \\
\hline & \multirow{2}{*}{ Criminal } & Prevention & $22.01050^{*}$ & 4.50620 & .000 & 11.2737 & 32.7473 \\
\hline & & Traffic & $10.92411^{*}$ & 4.56936 & .049 & .0369 & 21.8113 \\
\hline \multirow{6}{*}{$\begin{array}{l}\text { Avoidance-focused } \\
\text { strategy }\end{array}$} & \multirow{2}{*}{ Prevention } & Traffic & 1.56618 & 2.44542 & .798 & -4.2604 & 7.3928 \\
\hline & & Criminal & -3.91597 & 2.53380 & .275 & -9.9532 & 2.1212 \\
\hline & \multirow{2}{*}{ Traffic } & Prevention & -1.56618 & 2.44542 & .798 & -7.3928 & 4.2604 \\
\hline & & Criminal & -5.48214 & 2.56931 & .089 & -11.6039 & .6397 \\
\hline & \multirow{2}{*}{ Criminal } & Prevention & 3.91597 & 2.53380 & .275 & -2.1212 & 9.9532 \\
\hline & & Traffic & 5.48214 & 2.56931 & .089 & -.6397 & 11.6039 \\
\hline
\end{tabular}

*Difference in means significant at 0.05

den. The results showed that the tested prevention police officers and traffic police officers were more likely to adapt problem-focused strategies in stress situations. This means that in difficult, stressful situations these officers take up measures aimed at solving the problem by means of cognitive transformation or attempts to change the situation. Criminal police officers are most prone to adapt the emotion-focused strategy. This strategy is typical for individuals who, when encountering a stressful situation, tend to focus on themselves and their own emotions felt in particular situations. These actions are aimed at relieving the tension; however, they may cause a surge in negative emotions. Avoidance-focused strategy was the least-popular stress-coping strategy adapted by police officers in all three force divisions. This strategy is characterized by a tendency to evade, and avoid thinking of, worrying about and experiencing the difficult, stressful situation. 


\section{DISCUSSION}

The article demonstrates the relationships between the sense of coherence and stress-coping strategies in police officers serving in different force divisions, thus verifying Hypothesis 1. Statistically significant correlation coefficients were identified between high sense of coherence and stress-coping strategies such as problem-focused strategy (positive correlation), emotion-focused strategy (negative correlation) and avoidancefocused strategy (negative correlation). Thus, one may conclude that police officers who adapt the emotion or avoidance-focused strategies (in this case, the officers of the criminal division, in whom the emotion-focused strategy prevailed) are characterized by a lower sense of coherence.

Results obtained in the police officers seem to corroborate the theses proposed by A. Antonovsky (1995), suggesting that individuals with a high sense of coherence are characterized by the ability to choose the most appropriate stresscoping strategies, while individuals with a lower sense of coherence would adapt less favorable strategies of coping, which is consistent with the literature data, particularly with data suggesting a non-linear relationship between the sense of coherence and the intensity of stress (Kazimierczak, Strelau, Zawadzki, 2012). This is also confirmed by the results of our studies as regards the hypothesis assuming the existence of differences between the sense of coherence in policemen serving in different force divisions characterized by different intensity of stress situations.

The analysis of the presented results revealed that police officers serving in different force divisions are characterized by different levels of the sense of coherence. The officers in the traffic and criminal divisions are characterized by lower sense comprehensibility, lower sense of manageability and lower sense of rationality as compared with the officers of the prevention forces. Highest statistical differences were observed between the subjects serving in the prevention police forces and the criminal police forces; the differences were observed in relation to all three components of the sense of coherence. Statistical comparison of prevention and traffic police forces revealed highest statistical differences with regard to the sense of comprehensibility and rationality, the differences in the sense of manageability were the lowest.

In addition, policemen from the prevention forces were characterized by the highest sense of coherence. Thus, it may be concluded that individuals who serve in this force division are characterized by high perception of the stimuli origi- nating from their inner or outer environment as being structured, predictable and explicable. In addition, they perceive their available resources to be sufficient to cope with the life's demands, as well as consider the external demands to be worth their efforts and involvement. Due to the fact that the sense of coherence is three-dimensional rather than unidimensional construct, relationships between the three components may be described.

The sense of comprehensibility was the strongest element of the sense of coherence in tested police officers. This means that they interpreted the perceived stimuli as structured and clear rather than chaotic and disorderly. Perhaps this could be due to the fact that police work is governed by particular service rulebook, precisely defined working hours and scope of duties.

The sense of rationality was found to be the weakest element. This dimension is related to the degree the policemen perceive the problems and challenges of their service to be worth their effort, dedication and involvement. The officers of the traffic and criminal forces had slightly lower sense of coherence, with their overall scores in the Life Orientation Questionnaire being within the average range. This means that they perceive the outer world as well as themselves, their emotions, needs and behaviours as rather comprehensible, structured, consistent and clear. Future appears to be predictable to them. They believe they could rather manage the problems they may encounter in life. They are moderately motivated to act. They usually think that life has sense to it and that at least part of the problems they may encounter in life are worth their effort, dedication and involvement. Sometimes, however, difficult problems may be a discouragement towards life. In such cases, they are perceived as obstacles that are difficult to overcome rather than challenges worth undertaking.

The sense of manageability was the strongest dimension of the sense of coherence in both groups. The sense of manageability defines the degree to which the individual perceives the available resources as sufficient to cope with the demands posed by the incoming stimuli. When the stimuli are undesirable, individuals may consider it highly likely that everything would turn out as well as could be reasonably expected. In the worst case scenario, they expect the consequences of undesirable events to be bearable. The resources required to cope with the demands are the resources owned by individuals themselves or by individuals they trust and may count on. 
The weakest component in both these groups was the sense of rationality; similar as in prevention police officers. The above analyses are consistent with the literature data that include recommendations for police psychologists of the 21 st century to include the sense of coherence as a personality trait responsible for ability to cope with work-related stress in their candidate screening tests (Kurke, Scrivner, 2009).

\section{CONCLUSIONS}

1. The sense of coherence is correlated to the stress-coping strategies. Highest positive correlation coefficients were observed between high sense of coherence and problem-focused stress-coping strategy, while negative coefficients were observed between high sense of coherence and emotion- or avoidance-focused stress-coping strategies.
2. Officers serving in different police forces tend to present different levels of the sense of coherence. Prevention police officers are characterized by the highest sense of coherence as compared to traffic police officers and criminal police officers.

3. Officers serving in different police forces tend to prefer different stress-coping strategies. Problem-focused stress-coping strategies are chosen most often by prevention police officers and traffic police officers.

\section{AUTHORS' DECLARATION:}

Study Design: Janina Maciejczyk, Przemysław Liszka; Data Collection: Janina Maciejczyk, Przemysław Liszka; Statistical Analysis: Janina Maciejczyk, Przemysław Liszka; Manuscript Preparation: Janina Maciejczyk, Przemysław Liszka; Funds Collection: Janina Maciejczyk, Przemysław Liszka. The Authors declare that there is no conflict of interest.

\section{REFERENCES}

1. Antonovsky, A. (1979) Health, stress, and coping. San Francisco: Jossey Bass.

2. Antonovsky, A. (1995) Rozwikłanie tajemnic zdrowia. Warszawa: Wydawnictwo IPN.

3. Czerwiński, W. (1998) Policja. Podstawowe przepisy prawne. Toruń: Wyd. Dom Organizatora.

4. Dąbrowska, I.U., Iwan, M.B., Żaboklicka-Madziar, M. (2007) Policjanci. In: Terelak, J.F. (eds). Stres zawodowy: Charakterystyka psychologiczna wybranych zawodów stresowych. Warszawa: Wyd. UKSW.

5. Dudek, B., Makowska, Z. (1993) Psychometric characteristics of the Orientation on Life Questionnaire measuring sense of coherence. Polish Psychological Bulletin. 24 (1). 309-318.

6. Endler, W.S., Parker, D.A. (1990) Multidimensional assessment of coping: a critical evaluation. Journal of Personality and Social Psychology. 58. 844-854.

7. Gruszczyńska, E. (2004): Poczucie koherencji (SOC) a proces radzenia sobie ze stresem: w poszukiwaniu mechanizmów działania SOC. Przegląd Psychologiczny. 47 (1). 77-91.

8. Heszen-Niejodek, I. (1996) Stres i radzenie sobie: główne kontrowersje. In: Heszen - Niejodek, I., Ratajczak, Z. (eds). Człowiek w sytuacji stresu. Problemy teoretyczne i metodologiczne. Katowice: Wydawnictwo Uniwersytetu Śląskiego

9. Jelonkiewicz, l., Kosińska-Dec, K. (2001) Poczucie koherencji a style radzenia sobie ze stresem: empiryczna analiza kierunku zależności. Przegląd Psychologiczny. 3. 337-347.

10. Kazimierczak, I.E., Strelau, J., Zawadzki, B. (2012) Search for a curvilinear relationship between the sense of coherence and the intensity of PTSD in MVA survivors. Anxiety, Stress and Coping: An International Journal. 25 (4). 443-455.

11. Kurkle, M.J., Scrivner, E.M. (2009) Police psychology into the 21st century. New York: Psychology Press.

12. Lazarus, R.S., Folkman, S. (1984) Stress, appraisal and coping, New York: Springer Publishing Co.

13. Maslach, C. (2003). Job burnout: New directions in research and intervention. Current Directions in Psychological Science. 12 (5). 189-192. 
14. Mroziak, B., Czabała, J., Wójtowicz, S. (1997) Poczucie koherencji a zaburzenia psychiczne. Psychiatria Polska. 3. 257-268.

15. Ogińska-Buliki, N. (2003) Stres zawodowy u policjantów. Źródła - konsekwencje - zapobieganie. Łódź: Wyd. WSHE.

16. Pasikowski, T. (2000) Stres a zdrowie. Poznań: Wyd. Fundacji Humaniora.

17. Piórkowski, K. (2008) Poczucie koherencji a style radzenia sobie ze stresem dowódców-żołnierzy zawodowych. Polskie Forum Psychologiczne. 13 (1). 50-60.

18. Szczepanik, P., Strelau, J., Wrześniewski, K. (1996) Diagnoza stylów radzenia sobie ze stresem za pomocą polskiej wersji kwestionariusza CISS Endlera i Parkera. Przegląd Psychologiczny. 39 (1). 187-210.

19. Terelak, J.F. (2008) Człowiek i stres. Bydgoszcz - Warszawa: Oficyna Wydawnicza Branta.

20. Terelak, J.F., Gumkowska, A.K. (1997) Poczucie koherencji a palenie sytuacyjne u studentów. Studia z Psychologii. 8. 38-77.

21. Terelak J.F., Siegoczyńska N. (2007) Poczucie koherencji a radzenie sobie za stresem u personelu pokładowego PLL LOT. Polski Przegląd Medycyny Lotniczej. 13 (1). 9-23.

22. Volanen, S., Suominen, S., Lahelm,a E., Koskenvuo, M., Silvetoinen, K. (2007) Negative life events and stability of sense of coherence: A five-year follow-up study of Finnish women and men. Scandinavian Journal of Psychology. 48 (5). $433-441$.

23. Waszkowska, M., Dudek, B. (2001) Poczucie koherencji a zdrowotne następstwa stresu zawodowego. In: Sęk, H., Pasikowski, T. (eds). Zdrowie-stres-zasoby. O znaczeniu poczucia koherencji dla zdrowia. Poznań: Wyd. Fundacji Humaniora.

Cite this article as: Maciejczyk J, Liszka P: Sense of coherence and stress-coping strategies in officers of different police force division. Pol J Aviat Med Psychol, 2013; 19(1): 37-48. 